\title{
Artigos
}

Persp. Teol. 33 (2001) 13-31

\section{BIOÉTICA E TEOLOGIA: JANELAS E INTERPELAÇÕES ${ }^{1}$}

Márcio Fabri dos Anjos CSsR

A rede de relações entre a bioética e a teologia é ampla e se abre a múltiplas interfaces. Gostaríamos de esboçar aqui o conjunto destas aproximações, ressaltando alguns pontos em que a teologia é, ao mesmo tempo, companheira e, de certa forma, aprendiz com a bioética, na tarefa de discernir caminhos para o futuro da humanidade. Estamos atentos também ao freqüente interesse por uma visão de conjunto dos problemas levantados pela bioética, hoje, e para os quais se conta com o subsídio teológico. Fizemos, por isto, uma tentativa de mapear as principais questões atuais em bioética, com um destaque às questões de biogenética humana, anotando algumas provocações mais significativas para a teologia ${ }^{2}$. Estaremos, assim, como que abrindo janelas para observar alguns panoramas em que teologia e bioética se encontram juntas; interpelam-se e se ajudam.

\section{Algumas raizes comuns}

Tomando como marco referencial para o nascimento da bioética ${ }^{3}$ os trabalhos de Potter e Hellegers, na década de 1970, pode-se dizer

\footnotetext{
' Aula inaugural proferida no dia 05/03/01, por ocasião da abertura do Ano Acadêmico do Centro de Estudos Superiores da Companhia de Jesus em Belo Horizonte. 2 Note-se que, quando falamos teologia, estamos aqui nos atendo à teologia católica ocidental, vista especialmente a partir do contexto latino-americano.

${ }^{3}$ A. JONSEN, The birth of bioethics, New York: Oxford University Press, 1998.
} 
que a teologia estava bem presente nesse nascimento. De fato, a teologia já sustentava, até então, uma boa tradição de análise e propostas em torno de problemas éticos aguçados pelos avanços tecnológicos. Chamavam mais a atenção as incidências em termos de ética médica ${ }^{4}$, mas também preocupações de cunho mais social estavam presentes, como as exigências e condições da paz mundial, os sistemas políticosociais, as comunicações de massa, o meio ambiente. O Concilio Vaticano II (1962-65) e vários documentos da Igreja desse período, mostram as preocupações de cunho mais abrangente com os destinos da humanidade. ${ }^{5}$ O nascimento da bioética se dá, além disso, antecedido pelo nascimento da "teologia da política", na Europa, e da "teologia da libertação", na América Latina. Retomamos este ponto mais adiante.

Olhando os tempos de hoje, chama a atenção que um teólogo, Alistair Campbell, tenha sido recentemente o presidente da IABInternational Association of Bioethics; que $T$. Engelhardt, notório bioeticista contemporâneo, tenha publicado em nossos dias uma obra de fôlego, postulando uma fundamentação da bioética em critérios da tradição cristã do primeiro milênio. ${ }^{6}$

Entretanto, mais importante do que enfatizar a presença da teologia no nascimento da bioética, é perceber os pontos de encontro da bioética e da teologia em algumas preocupaçōes fundamentais. Esta posição abre certamente um campo de mútuo enriquecimento, onde a teologia não apenas contribui, mas também pode encontrar estímulos de crescimento em sua reflexão. Ressaltamos apenas três pontos:

\subsection{Uma questão de "Salvação"}

Não há como não perceber as grandes e rápidas mudanças que ocorrem em nossos tempos, desafiando a responsabilidade humana em projetar o futuro. Esta percepção implica naturalmente em uma análise dos grandes avanços e mudanças que estão acontecendo. A questão de fundo que perpassa estas preocupações pode ser formulada em termos de salvação. Este conceito é, certamente, mais veiculado em teologia do que em bioética. Entretanto, também a bioética navega com esta preocupação de fundo: como construir um futuro que garan-

\footnotetext{
- Destacam-se entre nós as obras mais conhecidas de B. HÄRING. Mas vários outros poderiam ser lembrados, como Richard McCormick, Josef Flechter, Paul Ramsey,

${ }^{5}$ Cf. particularmente, do ConcílioVaticano II, a Constituição Pastoral Guudium et Spe's (1965), AAS 58 (1966) 1025-1116; PAULO VI, Encíclica Populorum Progressio (1967), AAS 59 (1967) 257-299; PAULO VI, Carta Apostólica Octogesima Adveniens (1971), Osservatore Romano, $15 / 05 / 1971$.

"H. TRISTAM ENGELHARDT Jr., The Foundations of Christian Biocthics, Lisse: Swets \& Zeilinger, 2000.
} 
ta no mínimo a sobrevivência da vida, e para além disto, um futuro de crescimento integral e paz. ${ }^{7}$ Empolga, mas também amedronta o crescimento do poder tecnológico nas mãos humanas, que torna seus detentores cada vez mais responsáveis pelos processos da vida. $O$ futuro imediato passa a ser preocupação, especialmente na medida em que o uso equivocado desse poder apresenta grandes mostras de devastação e alerta para a possibilidade de iminente colapso.

Os conceitos de "salvação" obviamente não são coincidentes em bioética e em teologia. Transcendencia e escatologia marcam o horizonte da visão teológica; enquanto que a bioética, de modo geral, cultiva um âmbito intra-histórico da sobrevivência e realização humana. Mas há pontos inegáveis de aproximação entre ambas as percepções. Um lado jornalístico desta aproximação se dá quando as tecnologias tocam em pontos da escatologia, p. ex., ao acenar para uma possível "imortalidade humana", através de alterações genéticas no relógio biológico. Ou levam à questão sobre o papel criador de Deus frente ao conjunto de interferências humanas na produção da vida ${ }^{8}$.

Entretanto, há outras aproximações de cunho mais metodológico. A importancia da transformação histórica foi recolocada com novo vigor pela teologia do político e pela teologia da libertação. Na coerência desta postura, a teologia se vê hoje diante do desafio comum em salvar a humanidade, seu meio ambiente e toda forma de vida que the faz parceria. A teologia encontra então, na bioética e na ecologia, grandes aliadas para repensar este braço imanente da salvação. E não é de se admirar, que tenhamos por parte de expoentes de nossa teologia, um crescimento no estreito diálogo com as ciências e tecnologias de ponta e suas incidências na vida, de modo até a suscitar perguntas se este deslocamento não implicaria em perder os pobres como interlocutores e destinatários preferenciais da preocupação evangélica." A vida dos pobres é inserida no contexto planetário ameaçado e no conjunto de recursos para reinterpretar e projetar a vida humana em sua globalidade.

\subsection{Espiritualidade e Mistica}

Espiritualidade e mística são aqui dois termos com raízes etimológicas diferentes que, entretanto, visam colocar em pauta uma pergunta fundamental em que se encontram bioética e teologia: o dina-

7P. Van RENSSELAER, "Bioethics, the science of survival", Perspectives in Biology and Medicine 14 (1970) 127-153; "Biocybernetics and survival", Zygon 5 (1970) 229-246, Bioethics, bridge to the future, Englewood Cliffs, N]: Prentice Hall, 1971.

"Cr. o "teológico" título da geneticista Fátima OLIVEIRA, Engenharia Genética: $O$ sétimo dia da criaçăo São Paulo: Moderna, 1995, $3^{\text {a }}$ ed.

${ }^{y}$ Cf. L.C. SUSIN (org.), A sarça ardente. São Paulo: Paulinas, 2000. 
mismo e as motivações escondidas que presidem a condução consciente da vida e de seus processos. A formulação deste conceito é decididamente teológica. Mas a constância de sua presença na bioética é uma realidade que a teologia tem ajudado a evidenciar. Há mais tempo a teologia vem chamando a atenção sobre a "luta dos deuses" que preside as escolhas humanas, e as formas religiosas subjacentes às relações econômicas e de mercado. Mesmo superando a demonização do mercado, persiste a identificação de opções de fundo que presidem e dinamizam a atividade humana. Nossa reflexão pessoal tem enfatizado a importância da "mística" na bioética; e como a qualidade desta "mística" afeta a qualidade da bioética que se elabora (como perceber o lugar dos pobres, os conceitos de autonomia e vulnerabilidade, de inclusão e participação). ${ }^{10}$ Concepções liberais aplicadas à bioética, para além de uma questão de métodos operacionais, fazem necessariamente apelo a um horizonte de sentido e motivação mais amplo para a condução da vida. Neste sentido, mesmo os postulados de uma ética sem nenhuma escatologia transcendente não parecem prescindir de um "credo" ou "santuário" que referende o dinamismo de suas propostas; nem parecem dispensar

A importância da "mística" na bioética tem sido realçada pela constante presença das religiões nos diferentes fóruns de sua discussão. $A I A B$, associação internacional de bioética mostra isto com clareza. Além disto, a discussão sobre este assunto vem sendo retomada com freqüência. Em uma menção explícita à "mística", A. Campbell chama a atenção para o risco de a bioética se tornar homogeneizada e prisioneira de consensos rasteiros, feita de concessões ao minimalismo dentro do pluralismo social. De forma mais ampla e fundamentada, Tristam Engelhardt, em sua obra The foundations of christian bioethics, afirma com todas as letras a importante contribuição da mística cristã para a bioética. Na introdução de sua obra afirma: "É aqui que se resolve o enigma e se encontra a porta no horizonte da imanência: o cristianismo abre uma imediata experiência das energias não criadas de um Deus radicalmente transcendente e pessoal. Aqui as soluções filosóficas e a verdade teológica coincidem: a verdade é Alguém. Tal teologia é conseguida asceticamente pelas fronteiras da oração para o arrependimento expresso em adoração. Dentro de tal teologia, a bioética é um caminho de vida. Ela só pode ser apresentada por um convite a se entrar nela. Para a questão 'Como posso conhecer a verdade?', recebe-se primeiro e antes de tudo um convite para a transformação ascética. É o 'puro de coração que verá a Deus' (Mt 5,8)."11 E, mais

\footnotetext{
${ }^{10}$ M.F. dos ANJOS, "Bioética nas desigualdades sociais", in V.GARRAFA / S.I.F. COSTA, $A$ bioética no século XXI = Saúde, cidadania e bioética, Brasília: UNB, 2000, pp. 47-65. "H.T. ENGELHARDT Jr., The Foundations of Christian Bioethics, Lisse: Swets \& Zeitlinger, 2000, "Preface" p. XIII.
} 
adiante, sem receio afirma que "este volume fundamenta a bioética dentro de uma teologia ascética e litúrgica, confiante em que sua inspiração provém do mesmo Espírito que inspirou as Escrituras e dirigiu os Apóstolos" ${ }^{12}$ As posições do autor podem ser polêmicas, como veremos adiante, mas postulam inegavelmente um lugar para a mística na bioética.

\subsection{Questões pontuais de ética}

Um terceiro lugar de encontro entre teologia e bioética podem ser as múltiplas questões de ética, particularmente as que emergem das novas tecnologias aplicadas à produção, reprodução e condução da vida. Este lugar certamente é mais empolgante, porque cercado pela novidade, pela ênfase recebida nos meios de comunicação, e pela crise em que coloca muitos pressupostos estabelecidos. Mas, para além desta dose de espetáculo, a reflexão de ambas as disciplinas tem uma tarefa árdua que consiste em saber identificar quais são as questões mais relevantes e desafiadoras para a ética, e ao mesmo tempo, com quais critérios possam ser encaminhadas. O ponto crucial se torna portanto uma questão de metodologia e de fundamentação. Até que ponto as novas possibilidades tecnológicas de realizar a vida podem ser avaliadas à luz de fundamentos anteriores a elas, e qual a força dos antigos critérios para avaliar os novos procedimentos? Para uma adequada introdução a estas questões, parece interessante uma breve referência à abrangência da bioética e à trama pela qual ciência e tecnologia se colocam como questões éticas.

\section{Para além da "biomédica" e da "biogenética"}

Existe uma questão que, embora já suficientemente ventilada, é útil lembrar. Quando se menciona "bioética", o imaginário corre velozmente para as questões de biologia, as aplicações das conquistas com o "projeto genoma", a engenharia genética, a reprodução humana assistida, os dilemas surgidos nas áreas médicas. De fato, as origens da bioética se misturam com a ética médica, e a biologia molecular está entre suas preocupações primeiras. Sem dúvida, os desdobramentos da biologia molecular persistem como uma fundamental interrogação ética, o que justifica que hoje continuem ocupando um lugar de realce no debate bioético. Entretanto, é importante notar que a preocupação formal que acompanha os avanços biológicos aparecem já de início em termos de "sobrevivência". ${ }^{13}$ No fundo, como humanizar os avanços

12 Ibidem, p. XVII.

${ }^{13}$ Cf. p. ex. o título da obra de Potter, citadas anteriormente (nota 7). 
científicos e as aplicações da tecnologia, assumindo com responsabilidade ética a construção do futuro.

Mas logo se percebe que a sobrevivência da vida no futuro depende de um intrincado maior de injunções. A deterioração do meio ambiente e a corrupção das formas de relações humanas favoráveis à vida são apontados como dois fatores dos mais importantes. Não seria então possivel excluir da bioética a consideração dos sistemas políticos e econômicos que determinam em grande parte os rumos da vida no planeta, as próprias pesquisas biológicas e a aplicação de seus resultados. A discussão atual sobre os transgênicos pode ser um rápido exemplo: envolve aspectos de saúde a curto, médio e longo prazo; traz perguntas de cunho filosófico; envolve questões econômicas; e se abre inclusive a políticas nacionais e internacionais como bem o demonstra a briga pelas patentes.

Este enfoque macrossocial é uma perspectiva muito cara à teologia da libertação. Pudemos uma vez aplicar esta leitura às pesquisas em genética humana em um artigo sobre "Poder, ética e os pobres na pesquisa em genética humana". ${ }^{14}$ Para o nosso contexto brasileiro já se entende que dar um "enfoque bioético" significa analisar o objeto em questão dentro da grande rede de relações humanas e ambientais, sob o ponto de vista do favorecimento à vida. Assim, um assunto de ética médica, como p. ex. a autonomia do paciente, ganha em bioética uma abrangência que interroga, entre outras, também as bases sociais da autonomia fora do ambiente hospitalar, mas certamente com influxo dentro dele. Os estatutos da IAB - associação internacional de bioética - define a bioética como "estudo dos aspectos éticos, sociais, legais, filosóficos e outros aspectos afins inerentes à assistência médica e às ciências biológicas". ${ }^{15}$ Medicina e biologia estão evidentemente em destaque nesta opção, em posição de objeto material do estudo; mas as formalidades do estudo são bem mais amplas.

De 2 a 4 de novembro de 2002, o Brasil estará abrigando, em Brasilia, o $5^{\circ}$ Congresso Internacional de Bioética. Como anfitrióes e organizadores do evento, já propusemos e foi aceito o tema geral "Bioethics: power and injustice". De um lado, uma conquista, por se ter a chance de explorar a dimensão da injustiça como o grande desafio da bioética; e não se ater simplesmente à busca de consensos diante das novas possibilidades e novos dilemas trazidos pela biotecnologia. Mas, de saída, sabe-se que estamos longe de uma univocidade

it MF. dos ANJOS "Poder, ética e os pobres na pesquisa em genética humana", Concilitum (B) $275 / \mathrm{n}^{\circ} 2$ (1998) 237-248.

is A. CAMPBELL, "Uma visão internacional da bioética", in V. GARRAFA / S.I.F. COSTA ... Op. cit, p. 27. 
conceitual neste assunto. Tendências divergentes interpretam a "justiça" em uma chave de alocação de recursos ou de distribuição eqüitativa de lucros e danos entre os que participam das pesquisas. Uma justiça que não chega à distribuição eqüitativa das chances de participação na vida social. ${ }^{16}$

\section{Avanços científicos: Ebulição na rede de relações e de significados}

Para se compreender bem as mútuas relações entre bioética e teologia, com seu intercâmbio de interrogações e propostas, parece fundamental fazer ao menos uma referência ao grande contexto sóciocultural marcado pela ciência e tecnologia, no qual nos situamos. O assunto é amplo e conta com inúmeras publicações que buscam analisar os diferentes aspectos deste nosso momento civilizatório. Para o que nos interessa nesta aproximação, bastaria talvez apenas apontar três campos de incidências cruzadas que nos permitem, a seguir, mapear alguns principais grupos de questões que envolvem teologia e bioética na reflexão ${ }^{17}$.

Um primeiro campo é certamente o próprio avanço da ciência e tecnologia em nossos dias. Sem entrarmos na intrincada discussão sobre o que é ciência, podemos assumir a genérica distinção de três componentes que diversamente as integram: o fatual (verificável, experimentável, aplicável); o formal (reflexivo, hermenêutico, interpretativo); o metodológico (instrumental). Percebemos então com certa facilidade como se dá hoje um tipo de endogênese de ciência e tecnologia, numa espiral crescente. Novos instrumentos e métodos, originários de verificações e hipóteses (componente formal), ampliam a verificabilidade e a capacidade de transformação (tecnologias) e incidem em avanço e/ ou desafio da leitura (ciência) formal, responsável pelos sentidos e significados.

Um exemplo típico para nossos tempos é o computador. A informática veio como um recurso de pesquisa e elaboração do conhecimento, que se torna hoje praticamente indispensável até na simples elaboração de uma monografia de bacharelado. Abre inúmeras possibilidades de produção de novos materiais e instrumentos, de avanço

${ }^{16}$ Cf. um dos clássicos no tema, J. RAWL Theory of justice, Cambridge: Harvard University Press, 1971. Cf. também E. SIQUEIRA, "O princípio da justiça", in S.I. COSTA / G. VOLNEI / G. OSELKA (orgs.) Iniciação à bioética, Brasília: CFM, 1998, pp. $71-80$.

${ }_{17}$ Já utilizamos este recurso para compreender os desafios da elaboração ética de novas gerações, in M.F. dos ANJOS, "Juventude e crise de valores morais", REB 59 / n 235 (1999) 530-550. 
no conhecimento dos seres, na sua modificação e em sua mesma produção. Não se trata apenas de conhecer o existente e lhe conferir significados, mas se amplia a possibilidade de recriar. Este domínio das possibilidades intensifica o virtualismo de nossa experiência e chega mesmo a consagrar a "realidade virtual", um modo eletrônico de estimular nossa imaginação dos seres e da vida.

Seria difícil classificar a amplitude dos avanços científicos hoje. Até para quem trabalha em teologia, se torna útil correr os olhos na gama de pesquisas patrocinadas atualmente no Brasil por instâncias como o CNPq e a FAPESP. De qualquer forma, chamam a atenção os avanços na direção de instrumentos e materiais, que, por sua vez, permitem o conhecimento do macro e do microcosmos, abrindo a possibilidade de aproveitar melhor ou mesmo interferir e redirecionar seus processos, e até, sob certo sentido, criar novos processos e novas formas de vida. Dispensamos aqui a exemplificação de cada uma destas incidências, mas recolheremos mais adiante algumas que interpelam mais frontalmente a bioética e a teologia.

No Brasil, o avanço científico tecnológico é bem maior do que à primeira vista aparece. Nos noticiários que acompanharam a conclusão do mapeamento do genoma humano, informou-se que "o Brasil está colocado em segundo lugar entre os países que mais contribuíram com informações para o banco de genes internacional que propiciou aquela vitória"; "só no cromossomo 22, nossos cientistas identificaram mais de 200 genes novos - o que significa um terço do total encontrado. Fora isso, o País chegou a desenvolver uma nova estratégia de seqüenciamento genético, que pretende patentear." São Paulo inaugurou, no ano 2000, o maior centro de estudos genéticos da América Latina, voltado para as doenças genéticas hereditárias. "Mais de $95 \%$ dos fragmentos de genes identificados em tumores de cabeça e pescoço foram sequenciados pelo Hospital do Câncer em São Paulo". Chegou-se entre nós ao domínio de técnicas de seqüenciamento do DNA completo de um ser vivo, aplicado ao Xylella fastidiosa, bactéria do "amarelinho" que atinge os laranjais brasileiros. O Brasil ganha respeito mundial no desenvolvimento da "bioinformática, uma área crítica da genética que consiste na arte de usar computadores para remontar o quebra-cabeça de milhões de fragmentos de DNA e analisar os genes"; nossos pesquisadores criam programas no setor. "Há anos o Brasil tem a agronomia para a região tropical, mais desenvolvida do mundo. E, com o domínio da tecnologia de análise biomolecular, essa área avança, entre nós, com rapidez cada vez maior." Em 1995 já foram lançados cerca de 20 tipos de plantas geneticamente melhoradas. "De três anos para cá, coloca no mercado quase 100 por ano, criando plantas altamente produtivas, adaptadas a climas específicos e resistentes a pragas." Conseguiu tropicalizar a soja (Brasil é o 2" maior produtor do 
mundo); "produzir cenouras na entressafra (e mais produtivas); um tipo de feijão que produz $40 \%$ mais por hectare; um cajueiro anão que dá frutos mais doces; um algodão que já nasce verde, marrom ou creme, dispensando corantes químicos." Desenvolveu há pouco arma biológica (um fungo especializado) contra gafanhotos, cujo combate no mundo inteiro depende de produtos tóxicos. ${ }^{18}$

Nesta sumária descrição se percebe um segundo campo de incidências importantes para a bioética e a teologia: a reelaboração de sentidos e significados. Nossos conhecimentos não são apenas verificativos, mas também necessariamente interpretativos e dinamicamente criativos de sentidos e significados. Mesmo sem entrar na densa análise filosófica que esse tema merece, podemos notar que novas condiçóes tecnológicas de vida afetam o modo de nos compreendermos no tempo e no espaço; exigem reinterpretarmos os seres e a nós próprios.

Um exemplo bem circunscrito desse fato podem ser as recentes conquistas do seqüenciamento dos genes humanos. Para além das promessas de novos recursos biotecnológicos que daí derivam, e da dificuldade de cumpri-las, surge um momento de profunda reinterpretaçăo do ser humano no conjunto da vida. Segundo J. Craig Venter, presidente da Celera, uma das firmas responsáveis pelo projeto genoma, 0 seqüenciamento redefine o lugar do ser humano entre os seres vivos com uma contundencia proporcional àquela com que Copérnico redefiniu o lugar da terra no sistema solar. De forma jornalística se anunciariam alguns resultados dizendo que "Albert Einstein tinha apenas $1 \%$ mais genes do que um rato e $50 \%$ mais do que um nematódio, uma lombriga". ${ }^{19} \mathrm{Na}$ comparação com nossos parentes mais próximos, os macacos, as divergências nas seqüências entre os genomas do homem e do chimpanzé são extremamente pequenas, isto é, apenas $1,3 \%$, dando lugar a uma revisão profunda de conceitos que interpretam o próprio ser humano. "A idéia de que espécies diferentes são tipos distintos é normalmente tida como óbvia pelo público e por especialistas em bioética, mas é, em grande medida, uma noção estranha ao mundo pós-darwiniano dos biólogos modernos". ${ }^{20}$ Observa-se, com isto, uma intensa reinterpretação do ser humano na rede de seres vivos.

\footnotetext{
18 "Os avanços da ciência no Brasil", O Estado de São Paulo, 22/02/2001, caderno A, p. 3. Cf. também S. BIEHLER MATEOS, idem, 22/01/2001.

"G. STIX "Seqüenciamento dos genes humanos faz a ciência voltar a um estágio primitivo", O Estado de São Paulo, 25/02/2001, caderno A, p. 12.

${ }_{20}$ A. MAURON, "Genoma sem alma", Science 291 / n" 5 / 505 (2/02/2001) 831-832.

Citamos por Folha de Săo Paulo, 25/02/2001, caderno Mais!, p. 25.
} 
Não é difícil perceber que as interrogações logo se estendem a outros significados. A teologia trabalha eminentemente com sentidos e significados; e igualmente a bioética. Neste campo movediço da reelaboração de sentidos, a bioética abriga perguntas declaradamente teológicas, buscadas em antigas formulações, por exemplo, a soberania de Deus criador ameaçada talvez pela atual arrogância humana em mexer nos processos de transmissão da vida; o "momento de infusão da alma" na geração do novo ser humano; a questão da "identidade da alma" em clones humanos; e semelhantes. Como uma sábia matrona, a teologia sorri diante da imprecisão de conceitos e da fixação em formulações superadas. Mas isto não a dispensa de reconhecer a tensão metodológica interna de seus modelos; reconhecer também a necessidade de repropor, reformular; e principalmente admitir que, de repente, possa se surpreender com os limites de seus pressupostos até então usados para equacionar mudanças radicais nos processos da vida. Esperamos trazer mais adiante alguns exemplos sobre isto.

Um terceiro campo em que incidem preocupações teológicas e bioéticas pode ser identificado nas relações humanas e ambientais. De fato, verificamos com facilidade como o avanço tecnológico está implicado com esta rede de relações, abrindo tantos e diferentes cenários. Chama-nos a atenção, em primeiro lugar, o grande fenômeno da globalização em seu sentido amplo e não apenas financeiro e econômico. Logo, também, os atrativos da tecnologia abrindo recursos, comodidades, expectativas de qualidade de vida e longevidade.

Entretanto, o contraponto a este paraíso prometido também se torna evidente. Há um predomínio dos interesses econômicos e financeiros que cavam as desigualdades; as tornam crescentes e põem em crise o meio ambiente; os sistemas político-econômicos se mostram incapazes de enfrentar as grandes relações de produção; percebe-se um declínio do político e múltiplos pontos de crise cultural. ${ }^{21}$ Mais da metade da população mundial amarga a carência em necessidades básicas para simplesmente viver 60 anos com dignidade. Uma gigantesca luta pela concentração do poder se trava na humanidade e se manifesta nos diferentes âmbitos das relações. Instaura-se a lógica da exclusão a que estamos habituados a nos referir. Violência, corrupção e narcotráfico são alguns de seus frutos. Junto a este quadro humano deve-se agregar também as análises sobre a devastação ecológica do meio ambiente. Já se anuncia, por exemplo, a possibilidade de uma próxima guerra mundial na disputa pela água potável.

${ }^{21}$ P. ENGELHARD, L'Homme mondial: Les societés humaines peuvent-elles survivre?, Paris: Arléa, 1996. 
De uma forma talvez menos contrapositiva, poderiam ser lembrados os tipos de desafios que decorrem da exigência de adaptação aos novos tempos tecnológicos. Trabalho e lazer, por exemplo, são um binômio que exige uma recombinação social urgente em tempos em que a tecnologia altera profundamente as formas de produção. $O$ mesmo se dá nas formas de comunicação, e semelhantes. Em todos os desafios, se mostra a crescente responsabilidade, cada vez mais clara, de termos em nossas mãos, no presente, as decisões sobre o futuro. É assim em termos macrossociais: por exemplo as previsões apontam que em menos de cinqüenta anos, a população mundial atingirá 9,3 bilhões de habitantes, se tornando ainda mais pobre e mais idosa. ${ }^{22}$ Como cozinhar a refeição da vida para este futuro? É assim também em um contexto microssocial: por exemplo, os diagnósticos pré-natais avançam cada vez mais na diagnose preditiva. A pergunta é: o que significa uma fecundidade responsável, no presente, diante das previsões praticamente certas do futuro? Estamos acostumados a deixar tudo por "conta da natureza", não seria isto hoje uma forma de irresponsabilidade?

Estas breves referências são colocadas apenas para ilustrar como a bioética, enquanto interrogação ética às "ciências da vida" e carregando a preocupação com a sobrevivência, tem um quadro denso de desafios. Para seu enfrentamento precisa naturalmente de uma ampla referência a sentidos e critérios; e não pode prescindir de práticas que subsidiem as propostas éticas. A teologia, por sua vez, particularmente a que desenvolvemos na América Latina, tem tomado a peito as relações humanas como um grande lugar de "encarnação" da fé; e, portanto, um lugar de densidade da elaboração teológica. Tem, além disso, uma força de testemunho na acusação da exclusão, na busca de novas relações e de esperança para os pobres. Tem avançado também, evidentemente, na direção da ecologia e de diálogo com as ciências de fronteira.

Este ponto de encontro de bioética e teologia é, com certa facilidade, identificável por parte dos teólogos/as que lidam com bioética, ao deparar e mesmo se surpreender com um grande senso de justiça, solidariedade e humanismo que preside em grande parte a bioética. Mas também da parte de instâncias da bioética se mostra uma confiança na parceria com a teologia. Um exemplo claro está nas Normas para pesquisa envolvendo seres humanos, do Conselho Nacional de Saúde. Ali se promulga que os CEPs - Comitês de ética em pesquisa - atualmente espalhados pelo Brasil inteiro, incluam teólogos na com-

${ }^{22}$ ONU, "Perspectivas da população mundial", O Estado de São Paulo, 1/03/2001, caderno A, p.10. 
posição de seus membros; e na própria composição CNEP - Comissão Nacional de Ética em Pesquisa - se exige que sejam integrantes "oito personalidades com destacada atuação nos campos teológico, jurídico e outros". ${ }^{23}$ É também sintomático que a presidência na organização do próximo congresso internacional de bioética no Brasil esteja propondo que a conferência de abertura do congresso seja proferida por um teólogo brasileiro em destaque. Existe, assim, confiança e expectativa. Naturalmente, não é qualquer modelo teológico que pode corresponder a isto.

\section{Uma tentativa de mapeamento das questões atuais em Bioética}

Pode ser interessante ter uma visão geral de pontos mais recorrentes em bioética, hoje. Isto ajuda em teologia a perceber melhor a gama de solicitações para a reflexão, ao mesmo tempo em que para os teólogos/as se desenham os campos concretos em que aparecem as provocações teológicas. As classificações aparecem de modo direto ou indireto nas obras gerais de bioética. ${ }^{24}$ Como todas as classificações, também esta é provisória e limitada. Aplicamos aqui o antigo recurso do pensamento clássico para distinguir o objeto da bioética em seus aspectos formais e materiais. Podemos dividir primeiramente os campos "materiais" em três grupos, conforme o ciclo da vida: nascer, viver, morrer.

a) Questões relacionadas com o inicio da vida - Considera-se não apenas a vida humana, mas também a vida animal e vida vegetal, uma vez nos tornamos inseparáveis companheiros do viver. Entram aqui as questões de genética. No âmbito vegetal destacam-se principalmente a programação seletiva (transgênicos), e o aproveitamento farmacêutico, que tem determinado problemas de biopirataria no contexto de nossa fauna. No âmbito animal, distinguem-se as seleções genéticas e técnicas de reprodução (incluindo a clonagem) em vista do consumo alimentar. Mas há que se notar também as modificações genéticas em vista do xenotransplante. ${ }^{25}$ No âmbito humano, desenvolveremos mais adiante e com mais detalhes os avanços e desafios da área. Mas vale lembrar desde já os avanços técnicos não necessariamente relacionados com a genética, como os da reprodução assistida,

\footnotetext{
${ }^{23}$ Resolução CNS 196/96 cap. VII.4; cap. VIII.1

${ }^{24}$ Cf. L. PESSINI / C.P. BARCHIFONTAINE, Problemas atuais de bioética, $5^{\mathrm{a}}$ ed. revista e ampliada, São Paulo: Loyola, 2000, pp.28-32.

${ }^{25}$ N. GIRALDI, Os xenotransplantes à luz da bioética, in J.E. SIQUEIRA / L. PROTA

/ L. ZANCANARO Bioética: estudos e reflexões, Londrina: UEL, 2000, pp. 151-164.
} 
onde se pode incluir a clonagem, a FIVET, tipos de diagnóstico prénatal, barriga de aluguel e pesquisas em direção ao útero artificial.

b) Questōes relacionadas com a saúde, qualidade de vida, condiçôs relacionais humanas - Entende-se aqui que este campo tão amplo deva obviamente ser analisado sob os aspectos formais da bioética. Podem se destacar de modo geral: as políticas sociais, relacionadas, $\mathrm{p}$. ex., com moradia, educação, saúde e seguridade social; políticas populacionais e reprodutivas; sistemas econômicos e de produção, onde se situam emprego e relações de trabalho; questões pertinentes a relaçöes intergrupais, como relações de gênero, de etnias, de classes sociais, de diferentes culturais; questōes relacionadas com a pesquisa $e$ experimentação, onde ganham destaque os temas relacionados com a ética em pesquisa e o não menos candente assunto das patentes.

c) Questöes de ecossistema e meio ambiente - - Cada vez mais se percebe que a sobrevivencia da vida humana e do planeta como um todo passa por este campo. Merecem destaque as questóes de biodiversidade e de biossegurança.

d) Questöes relacionadas com "situnçöes-limite", doença e morte - Merecem realce as possibilidades de (xeno)transplantes, a eutanásia, a distanásia, as relações médico-hospitalares com os pacientes.

Cada um dos tópicos mencionados anteriormente abrem desafios específicos que nem sempre é fácil imaginar. Como toda disciplina, a bioética tem um ambiente de trabalho para seus referenciais formais, através dos quais desenvolve suas análises e propostas. Em uma classificação provisória como a anterior, distinguimos neste campo:

a) Questoes metodológicas globais - Entram aqui as discussões sobre o estatuto epistêmico da própria bioética e a discussão de seus princípios formais e sua abrangência material.

b) Questöes de metodologin transdisciplinar e intercultural - A bioética se depara neste ponto diante do pluralismo e da pluralidade, das convergências e divergências. Abre-se em diferentes tendências e modelos. Alimenta-se de distintas contribuições. Aqui se insere a participação das religiōes na bioética, com suas correspondentes teologias. ${ }^{26}$ O Islamismo tem estado presente, com muita evidência, nos congressos internacionais, cunhando inclusive a expressão de "bioética istâmica". No Brasil, o feminismo vem tendo uma crescente atuação na reflexão.

${ }^{2 h}$ Cf. Salide, religióses e espiritualidade, número monográfico de $O$ mundo da Saúde $24 / \mathrm{n}^{\prime \prime} 6(2000)$. 
c) Questões de conceituação fundante - Sob esse enunciado elencamos a elaboração da bioética quanto aos referenciais específicos que constituem seus critérios e presidem suas avaliações e propostas. Conceitos como natureza, pessoa humana, embrião, dignidade, responsabilidade, autonomia, equidade, são exemplos de conceituações fundantes que entram no debate atual. Este é um dos campos em que a teologia tem podido contribuir decisivamente na bioética.

d) Bioética formal aplicada - Neste ponto, aparecem as questões temáticas, que são tratadas segundo o enfoque específico da bioética; geralmente dando maior amplitude às questões que se encontram circunscritas dentro de uma área delimitada como p. ex. médica, sanitária, veterinária, agrária.

\section{Uma consideração específica a partir da Biogenética humana}

A este quadro pode-se somar uma consideração específica sobre as questões éticas que surgem a partir dos avanços relacionados com a genética humana. Os avanços nesta área têm ganhado constantemente os espaços nos noticiários, especialmente com a finalização do seqüenciamento do genoma humano, mas também causam curiosidade e sensação várias notícias sobre suas crescentes aplicações. Não entramos em uma avaliação dos próprios resultados, até agora obtidos, sobre o seqüenciamento. Talvez se deva notar apenas que em tal avaliação, existem tendências otimizantes, muitas vezes ligadas com interesses econômicos subjacentes; e tendências mais críticas e restritivas, não vendo a aplicabilidade tão segura nem tão ao alcance das mãos. ${ }^{27}$ Vejamos algumas questões principais que surgem para a bioética, a partir de um esquema simplificado de classificação de suas possíveis aplicaçōes.

Segundo o prof. Maurizio Mori ${ }^{28}$, o estudo da genética humana tem duas grandes finalidades: a) $O$ estudo do genes do indivíduo aduito, com uma fundamental aplicação na solução dos problemas de saúde. Os resultados deste estudo revolucionam a medicina. Suas formas de aplicação se abrem em três grupos principais:

- Teste genético - Este, por sua vez, se realiza como diagnóstico sintomático, pré ou assintomático, preditivo. O resultado da aplica-

${ }_{27} \mathrm{Cf}$. por exemplo discussões sobre clonagem terapêtica humana, em Folha de São Paulo, 15-03-2001, caderno A, p. 24.

28 Servimo-nos aqui de dados fornecidos em conferência pelo prof. Maurizio Mori, cf. M. MORI, "Espero que os homens façam melhor que Deus", Ser Médico, $n^{0} 14$ (2000) 2-9. 
ção dos testes gera um grande desafio de enfrentamento da realidade diagnosticada: administrar e conviver com o que não se pode modificar; ou então resolver o dilema de intervir ou não intervir. ${ }^{29}$

- Construção de uma "fármaco-genética" - Trata de identificar o perfil genético do indivíduo, suas energias e carências (objetivo biológico), e a partir daí elaborar a terapia gênica específica, isto é, personalizada. Segundo informações haveria hoje cerca de 500 sequências de DNA conhecidas e aproveitáveis na construção da cartografia genética humana. A previsão é de que em 2009 estarão conhecidas entre 18 e 20 mil. Isto permitirá que cada indivíduo tenha sua medicação e intervenção personalizada. Abrem-se aqui particularmente questões éticas de cunho político e econômico: quem terá acesso a estes recursos?

- Núcleo-transferência - Uma técnica que permite, entre outras, a seleção de características com a utilização de células-tronco, ${ }^{30}$ chegando à obtençâo de tecidos e órgãos especificos para efeito de transplante. A grande polêmica ética subjacente a esta questão está principalmente na clonagem (chamada de "clonagem terapêtica" to próprio indivíduo) e na subseqüente destruição de embriōes humanos para a obtenção das células-tronco. $O$ anúncio de técnicas mais recentes que contornariam tanto a necessidade de clonagem como a violação de embriões, aliviou um pouco a tensão existente.

b) Uma segunda finalidade do estudo da genética é analisar a transmissão dos caracteres hereditários. Sua aplicação abre em grandes linhas um novo conceito de família e de sociedade, pois este conhecimento não implica apenas indivíduos mas os próprios agrupamentos humanos e se estabelece uma relação entre os genes e o ambiente humano constituído por doenças e limitações humanas evitáveis. Assim, os diagnósticos genéticos serão uma rotina pré-nupcial que decidiria pelo menos a ética da reprodução no âmbito de um casal? Intervir com modificações genéticas ou não? Cresce, sem dúvida a responsabilidade humana. A Convenção Européia de Bioética de 1997 já discutiu sobre o direito a se ter um patrimônio genético não manipulado. Esta tendência de valorizar a biodiversidade genética construída pela ordem biológica dada se mostra também nas reivindicações por uma alimentação não transgênica. Estas questões desencadeiam em temas de biossegurança. ${ }^{31}$

${ }^{29}$ V. GARRAFA, "O diagnóstico antecipado de doenças genéticas e a ética", O Mundo da Saíde $24 / \mathrm{n}^{3} 5$ (2000) 424-428.

${ }^{33}$ H. LEPARGNEUR, "Células-tronco, mães de futura medicina regenerativa", O Mundo da saúde $24 / \mathrm{n}^{\circ} 6$ (2000) 495-509.

${ }^{31}$ J.L.T. de ALMEIDA, "Biossegurança no ano 2010: o futuro em nossas mãos?", Bioética $7 / n^{\prime \prime} 2$ (1999) 199-205. 


\section{A Teologia na argumentação em bioética}

Um tópico que não poderia faltar no quadro que estamos apresentando é perguntar finalmente como a teologia entra na discussão dos fundamentos da bioética e de sua leitura temática aplicada. Sabemos de antemão que a teologia, mesmo restrita à católica ocidental, se constrói em vários modelos. São suficientemente conhecidos também os principais pontos de tensão dos diferentes modelos quando se trata de bioética. Alguns exemplos seriam o conceito de natureza; o lugar da razão na argumentação teológica, especialmente quando se trata de ética teológica; os critérios éticos que regem a ação prática diante das perdas e ganhos resultantes da ação; o valor da vida nascente em seus diferentes momentos; e semelhantes.

$O$ aprofundamento destas questões nos remete ao estudo da relação entre fé e razão. Esse tema tem merecido a atenção do Magistério da Igreja ${ }^{32}$ e de especialistas que desdobram a questão. ${ }^{33}$ Vale lembrar também a obra de Manfredo de Oliveira, não somente por suas agudas análises sobre o tema, mas pelo tópico específico em que discorre sobre "teologia e ciências da vida como a nova metafísica". ${ }^{34}$ Para concluir o painel que nos propusemos, sem detalhar os modelos, gostaríamos de fazer uma rápida menção a três tendências atuais na condução do discurso teológico em bioética:

Discurso autoritativo da fé - Esta tendência parte de uma ênfase na ambigüidade humana de tal forma que "sua capacidade para conhecer a verdade fica ofuscada, e enfraquecida a sua vontade para se submeter a ela" ${ }^{135}$. Com isto, o discurso que vem da fé se sobrepõe ao da razão. "A possibilidade de conhecer a verdade plena sobre o valor da vida humana é oferecida ao homem pela palavra, a ação e a própria pessoa de Jesus" (Evangelium Vitae 29). Percebe-se, aqui, a força autoritatiza da fé, na etimologia primeira da palavra que remete a augere, isto é, significa força de ampliar, alargar horizontes, libertar. Neste sentido, se coloca uma compreensão do magistério na Igreja como um grande serviço de pedagogia e aprendizagem. O que acaba ocorrendo, entretanto, é a transformação do autoritativo em autoritá-

32 JOÄO PAULO II, Enciclica Fides et Ratio (Sobre as relaçôes entre fé e razão), 14/09/ 1998. São Paulo: Paulinas, 1998.

${ }^{33}$ Entre estes, cf. o capítulo de J.B. LIBANIO, "Teologia e interdisciplinariedade: problemas epistemológicos, questöes metodológicas no diálogo com as ciências", in L.C. SUSIN, Mysterium Creationis: Um olhar interdisciplinar sobre o universo, São Paulo: Paulinas, 1999 pp.11-43.

3. M.A. OLIVEIRA, Diálogos entre razão e fé, São Paulo: Paulinas, 2000, pp. 190-199.

${ }^{35}$ JOÃO PAULO 11, Encícica Veritatis Splendor, 06/08/1993, São Paulo: Paulinas, 1993, n.1; Cf. também JOÃO PAULO II, Encíclica Eungelium Vitae, 25/03/1995, São Paulo: Paulinas, 1995, n. 36. 
rio, esperando-se de autoridades constituídas a definição cabal de conceitos e critérios. ${ }^{36} \mathrm{E}$ isto parece um grande prejuízo, na medida em que se perde em teologia a perspectiva de discipulado, que se constitui base da proposta evangélica.

Discurso confessional da fé - Esta tendência poderia ser percebida na recente obra de H. Tristam Engelhardt Jr., sem querer com isto reduzir a obra do autor a este aspecto. Renomado autor em bioética, escreveu uma obra em 1991 ${ }^{37}$, buscando desenvolver os desafios de construir consensos éticos em meio ao pluralismo cultural e argumentativo. Parecia então um autor com enormes concessões ao liberalismo. Surpreendentemente publica, no ano passado (2000), outra obra onde a confessionalidade é praticamente colocada em seu crachá de autor. Ele relembra que na 2 " edição de sua obra, The foundations of bioethics ${ }^{38}$, ele já assumia o seguinte: "Sou, depois de tudo, um texano católico ortodoxo, nascido de novo, um convertido por escolha e convicção, pela graça e pela penitência. ${ }^{\prime \prime 39}$

Seria fora de propósito introduzir aqui uma análise da obra de Engelhardt, o que certamente começa a aparecer na literatura de bioética. ${ }^{40}$ Mas alguns traços de sua proposta podem ser realçados neste momento para ilustrar uma tendência que certamente se encontra também além de sua obra. Como vimos acima, ao falar da relação da bioética com a espiritualidade, o autor parte da afirmação de que a "verdade é Alguém". Não difere, neste ponto, das palavras anteriormente citadas do Papa João Paulo II, na Evangelium Vitae. Inquietase com a questão da transcendência da verdade, deixando-nos em nossas contingências históricas bastante perplexos: "Se a verdade não pode irromper até nós e, pessoalmente, nos dirigir, não vamos estar sempre perdidos na pluralidade de diversas percepções morais e religiosas no sentido de não sabermos que normas devem nos reger?"41

Sua proposta é recuperar o específico que a fé pode oferecer através de suas expressões religiosas: "quando as religiões se acomodam às pretensões da cultura secular, elas se tornam irrelevantes. Elas não têm nada de próprio para oferecer." E faz uma crítica direta ao lugar

\footnotetext{
${ }^{36}$ Cf. J. DESCLOS, O resplendor da verdadeira liberdade: Anotações sobre a Veritatis Splendor, São Paulo: Paulinas, 1998.

${ }^{37}$ H. T. ENGELHARDT Jr., Biocthics and secular humanism: The search of a common morality, Philadelphia: Trinity Press International, 1991.

${ }^{3 *}$ Idem, The foundations of bioethics, New York: Oxford University Press, 1996, p. XI

39 Ibidem, "Preface" p. XVI.

4) Cf. H. LEPARGNEUR, "Sobre a bioética ortodoxa de Engelhardt", in O Mundo da Salide (no prelo).

${ }^{41}$ Esta citação e as que seguem neste tópico estão no prefácio de H.T. ENGELHARDT Jr. The foundations of cliristinn bioethics, Op.cit., "Preface", pp. XI-XX.
} 
da razão em teologia dizendo: "Se a razão estiver no centro da teologia, reconstrói-se racionalmente o conteúdo de qualquer biótica cristã à imagem e semelhança da racionalidade moral secular". Na sua obra de mais de 400 páginas, a inspiração que o autor busca na patrística do primeiro milênio do cristianismo, não o impede de fazer uma análise do que chama de "bioética secular", de considerar posições de Kant, Hegel e Kierkegaard. Marca posiçóes claramente buscadas no horizonte da fé, criticando o mito da saúde e de uma felicidade plena dentro do tempo. "A moral secular perdeu o sentido da importância final de uma boa morte para a salvação", afirma declaradamente. Estas poucas observações, além de acenar para uma tendência do discurso teológico em bioética, podem servir também para despertar o interesse por uma obra que merece leitura e consideração.

Discurso argumentativo da fé - Esta terceira tendência valoriza exatamente a força da racionalidade alimentada pela fé. Enquanto na tendência anterior a fé é confessada e se mostra na frente, aqui a fé fica implícita nos argumentos que se tecem. Dietmar Mieth, respeitado bioeticista católico, integrante do Comitê de Bioética da Comunidade Européia, afirma que "não existe proposta ética cristã que não possa ser fundamentada racionalmente; e este é o discurso mais adequado para a bioética no mundo plural em que vivemos". ${ }^{42}$ O ponto de encontro do diálogo em bióética seria então o das argumentaçōes racionais. A ênfase na complexidade da realidade tem aqui também um papel importante. Não pode ser abarcada por uma só "ciência" ou "disciplina". Hugo Assmann relembra a distinção de Karl Popper ${ }^{43}$ entre verdade e certeza, para anotar que na vida não podemos prescindir de nossas verdades. E acrescenta que "Popper nos atropela, no entanto, com a injunção de que saibamos viver sem certezas, mergulhados apenas em pequenas verdades transitórias. Será que é esta a dinâmica da vida? Se for, ela precisa saber como tornar-se viável sem absolutos definitivos". E pergunta mais adiante: "Mas então, porque a teologia insiste tanto em verdades inabaláveis e conclusivas (...)? Como seria uma teologia do sentido provisório, dos modestos amores possiveis?"

Estas posições apontam para uma forma de discurso em bioética em que, primeiramente, os próprios teólogos/as assumem uma postura de parceiros na busca das certezas; e, com suas verdades (teológicas) contribuem nesta parceria. E em seguida, buscam expor os argumentos de suas verdades. Uma posição simpática para os interlocutores.

42 D. MIETH, "Theology, ethics and genetics", Boston: seminário no Boston College, 2000, (no prelo).

* K. POPPER, Um mundo de propensões. Lisboa: Fragmentos, 1991.

"H. ASSMANN, "Teologia e ciências, interdisciplinariedade e transdisciplinariedade",

in L.C. SUSIN Mysterium Liberationis, São Paulo: Paulinas, 1999, p.93. 
Na conclusão deste rápido painel pode-se talvez realçar que, no Brasil, temos um campo amplo e desafiador em que a bioética conta com uma substancial contribuição de nossa teologia. O ambiente é acolhedor, como tem ficado claro em congressos e eventos. Crescem rapidamente as ofertas de estudo universitário em bioética. É preciso, com urgência, termos mais gente trabalhando na área.

De qualquer forma, mesmo para quem nunca irá estudar bioética, é fundamental estar atento às transformações, deslocamentos e interpelações que aparecem com os avanços das ciências e tecnologias. É preciso escutar que estão batendo à porta de nossas igrejas e conventos. É o futuro que chegou. A pergunta é como acolhê-lo e brindá-lo com o bom vinho de Caná. Porque, no fundo, todo o esforço da bioética e da teologia se dirige a fazer da vida, não simplesmente uma sobrevivência, mas sim uma grande festa em que reine o progresso na justiça e na dignidade. E que os pobres possam, finalmente, tocar com as mãos o conteúdo da esperança.

Márcio Fabri dos Anjos CSsR - Doutor em Teologia pela Pontifícia Universidade Gregoriana (Roma-Itália), 1975, com a tese doutoral Argomentazione Morale e Aborto. Dalle argomentazioni sull'aborto al modo giusto di argomentare in Teologia Morale, sob a orientação do Prof. Dr. Joseph Fuchs, SJ. Atualmente é Professor de Teologia Moral no ITESP-Instituto Teológico S. Paulo e Membro da Diretoria da SBB-Sociedade Brasileira de Bioética (Comissão de Ética). Publicou: Sob o Fogo do Espírito, S.Paulo: Paulinas / SOTER, 1998. Teologia y Nuevos Paradigmas, Bilbao: Mensajero, 1999.

Endereço: Rua Oliveira Alves, 16404210-060 - São Paulo - SP

E-Mail: mfabri @ hydra.com.br 